\title{
ASSESSMENT OF THE GEOLOGICAL ENVIRONMENT IN RESPECT OF WASTE DISPOSAL IN SALT MINE WORKINGS
}

\section{Katarzyna POBORSKA-MEYNARSKA}

\author{
AGH University of Science and Technology, Faculty of Mining and Geoengineering; \\ al. Mickiewicza 30, 30-059 Krakow; \\ e-mail:kpm@agh.edu.pl
}

\begin{abstract}
The concept of waste storage in underground salt mines is to use the host rock environment as a geological barrier, preventing the migration of hazardous substances. European and Polish law defines the geological conditions and the safety of underground storage. According to national regulations, the underground storage site location is based on the results of geological research contained in the hydrogeological and geological-engineering documentation. This paper presents the principles for the assessment of the geological environment in a salt mine for the waste storage, in the context of national legislation. It has been shown that for the salt deposits a more detailed range of geological research has to be defined to prepare relevant documentation and to assess the possibility of waste storage in salt mines.
\end{abstract}

Key words: salt mine, underground waste disposal

\section{INTRODUCTION}

Underground salt workings that were developed during the salt deposit exploitation are used for industrial purposes other than salt extraction in many places of the world. One of the options is waste disposal both in shaft mines and salt caverns developed during brine production by the solution mining method. Commercial waste disposal in salt beds is a fairly new business existing only for about twenty years, with some exceptions. The method is practiced on an industrial scale in few salt mines, mainly in Germany, where considerable experience has been gained in that area. The first and the oldest site is the Herfa-Neurode facility which has been operating in the former potassium salt mine since 1972. Hazardous 
waste is accepted there, except for radioactive waste, with the capacity exceeding 200,000 t a year (www.ks-entsorgung.com ).

In the 1990s, several more underground disposal projects were completed in the abandoned underground workings of potassium and rock salt mines, under the following categories (Behnsen 2008, www.ks-entsorgung.com, www.uev.de/frame/frameset.html):

- salt mines as waste disposal sites: Zielitz and Heilbronn,

- salt mines utilising waste by using it after treatment in mining processes, mainly as a component of back-filling mixes: Bernburg, Hattorf, Kochendorf, Unterbreizbach, and Wintershall.

The storage facilities receive only certain types of waste, with strictly defined properties, e.g. the residue from municipal waste incineration plants, electrolytic waste, waste containing heavy metals, PCB etc. In 2005, an underground disposal facility was opened in the United Kingdom, in the part of former Winsford Salt Mine, collecting hazardous waste, e.g. certain chemicals and waste from thermal, metal, and plastic processing (www.veoliaenvironmentalservices.co.uk ).

The disposal of waste in leached-out caverns on an industrial scale is not common either. Many solution mined caverns have been used for dumping salt and chemical (sodium) waste, drilling spoil etc. for a number of years. However, those sites did not operate as do present disposal facilities. Currently, such disposal facilities are operated e.g. in the USA and Canada. They accept waste occurring during oil field exploitation. Similar sites exist in some European countries (United Kingdom and Holland).

The possibility of using abandoned salt-mine workings for waste deposition depends on a number of geological and technical factors: the geology of the salt deposit and its surroundings, hydro-geological and mining conditions, as well as operational conditions associated with salt extraction technologies or mine design.

Owing to the benefits offered by the underground storage and disposal method on the one hand and the risk of environmental pollution (of underground waters and biosphere) on the other hand, the EU countries, including Poland, have implemented the regulations to control the processes of underground storage placement, construction, and operation.

The surrounding geological environment contributes to the isolation of waste in an underground storage facility. Broadly understood geological conditions existing in a given environment decide about the possibility of storage sites and safe operation.

\section{THE PRINCIPLES OF WASTE ISOLATION IN AN UNDERGROUND STORAGE AND THE ROLE OF THE GEOLOGICAL BARRIER}

The main task of an underground waste disposal is to restrain the collected substances within the storage space and isolate them safely from the biosphere and underground waters (Behnsen 2008). 
Isolation is obtained by:

- the creation of artificial barriers (technical) in correlation with individual properties of waste,

- the natural geological barrier created by the rocks of salt deposit and its surroundings as well as geological and hydro-geological conditions.

An underground waste disposal facility can be placed within the existing or abandoned mine (Regulation of the Minister of the Environment of 28.12.2011). The effectiveness of waste isolation within the disposal space depends therefore on a number of factors, e.g. the type of waste, method of preliminary treatment and waste form for disposal, disposal process, mining conditions, geology of salt beds and their surroundings, water conditions, bed rock and surrounding rock properties etc., briefly speaking on the "waste-storage-rock mass system."

During the operation stage, the open access to the disposal space exists and regular process activities are conducted there, i.e. those associated with waste transportation and deposition, as well as sealing and backfilling and other mining operations related to the disposal site operation and closure. The period of underground disposal operation depends mainly on the site's volume, quantity of waste received, and disposal capacity. The period should be estimated to be about several dozens of years. After closure, the disposal facility works in the post-operational stage of long-term waste isolation. In that stage, the role of the geological barrier is of key importance (Poborska-Młynarska et al. 2001).

The term of "geological barrier" in the context of underground waste disposal appears in the Polish law as used in the Geological and Mining Law (of 9.06.2011): "Underground waste disposal facility is placed within a geological formation, constituting a natural geological barrier for possible migration of hazardous substances outside the boundaries of the space that may be affected by the anticipated hazardous influence of waste disposal." Specifically, the role of geological barrier is determined by the regulation concerning underground waste disposal facilities (Regulation of the Minister of the Environment of 28.12.2011): "Underground waste disposal facility is placed within a geological formation [...], constituting a natural geological barrier which should effectively isolate waste from the environment and limit the migration of hazardous substances to the degree in which they do not have any irreversible negative influence on the environment after closure of the underground waste disposal facility."

The legal documents of the European Union (Council Decision of 19.12.2000) mention the essential significance of the geological barrier and the necessity to evaluate the risk for the underground environment. The risk evaluation consists mainly in the evaluation of the geological barrier's effectiveness in the isolation of the disposal space. The risk evaluation is provided for the operating and post-operating stages. A comprehensive analysis should concern component evaluations of e.g. geological, geomechanical, hydrogeological, and geochemical aspects, as well as the influence of the site on the biosphere. 
Geological evaluation requires conducting research or attaining knowledge of detailed geological conditions, including e.g.: the studies and analysis of the types of rocks and soil, topography, location of the site and the frequency of faults and fissures occurrence in the surrounding rocks, and evaluation of the potential seismic activity on the area. That evaluation should indicate whether the rock environment is suitable for underground waste disposal.

Geomechanical evaluation is conducted to check and diagnose the geomechanical stability of the underground workings in the disposal area.

The aim is to verify whether:

- the workings may cause propagation of large deformations in the rock mass and on land surface, which deformations could influence the waste disposal operations or open the way for the connection of the disposal area with the biosphere,

- the stability of the workings is adequate to avoid the destruction of the disposal area structure during the operating stage,

- the disposed material represents the necessary stability, in compliance with the geomechanical properties of the surrounding rocks.

Hydrogeological evaluation is intended to recognize underground water flows, within surrounding rock layers, on the basis of detailed studies of the hydrogeological properties of surrounding rocks.

Geochemical evaluation is meant to check the current underground water composition and possible content changes with time, the types and quantities of the minerals filling fissures, to provide a qualitative mineralogical description of surrounding rocks, and to determine the influence of changes within the natural environment on the geochemical system.

It is also required to provide the evaluation of a possible influence of the waste disposal site on biosphere, with the completion of basic studies regarding a definition of the parameters of the natural background of the main biosphere components.

The legal regulations relating to underground waste disposal concern especially salt mines (Council Decision of 19.12.2002). The salt bed rocks play a double role for the disposal site: they surround the disposed waste and, together with the impermeable rocks in the overburden and floor (if such is the geological structure of the salt deposit), they create a geological barrier which can protect the disposal site against the influx of underground waters from the outside and can also stop the migration of gases or liquids from the disposal site outside. In that case, the only ways across the geological barrier would be the shafts and boreholes drilled from the land surface, which would first require sealing and tight and impenetrable plugging after the completion of the waste disposal operation. Consequently, according to the vision presented in the legal regulations, the salt deposit can provide the conditions, in the given geological situation, for full isolation of waste in the facility, which could be disturbed only by accidents or phenomena developing on a geological scale, e.g. earth crust movements or erosion. 


\section{GEOLOGICAL CONDITIONS FOR THE PLACEMENT OF A WASTE DISPOSAL FACILITY IN SALT MINE WORKINGS}

The geological conditions of an underground waste disposal site placement are determined in detail in the regulations (Regulation of the Minister of the Environment of 28.12.2011). According to that act, an underground waste disposal facility (other than neutral) may not be placed on such areas as: main underground water basins, increased seismic activity lands, fault zones, areas threatened by mass ground movements, intense subterranean erosion, the phenomena of suffosion and karst, the mining areas created for healing minerals, or when waste disposal breaches the principles of rational use of mineral deposits. The location for the underground waste disposal facility i.e. the selection of the geological environment presenting a geological barrier is chosen: "[...] on the basis of the results determined in the hydrogeological and geological-engineering documentation, specifying the conditions that describe the selected geological formations, in connection with underground disposal of specific types of waste."

Such conditions include the following (Regulation of the Minister of the Environment of 28.12.2011):

- thickness and strike of a geological formation,

- rock mass strength and convergence,

- number of aquifers with the parameters of underground waters,

- underground water flow rates and directions within the rock mass,

- overburden's permeability,

- fissure formation within the rock mass allowing for the migration of water solutions with corrosive properties,

- reactivity of rocks affected by solutions, including swelling, soaking, and dissolution,

- the volume of underground water inflow into the workings,

- methane content,

- temperature and pressures within the rock mass,

- site location in respect of other workings, taking into account current natural hazards from: water, methane, gas and rock ejection, coal dust explosion, and rockbursts.

Those conditions referring to the particular deposit and mine may be beneficial for the placement of an underground waste disposal site and, together with the designed artificial barriers, may create an effective isolation system for specific types of waste, which should be documented in the evaluation of the project's impact on the environment. Obviously, such conditions can turn out to be unreliable as well.

The geological conditions presented above have been subjected to preliminary analysis in respect of the geological relationships existing in the mineral deposits and underground salt mines in Poland (Kunstman et al. 2007). 


\section{Thickness and strike of geological formations}

The morphology of the bedded and dome salt deposits, their sizes, and locations of the geological boundaries should allow us to determine the area designated for an underground waste disposal, with the required volume, together with the protection zones. In the case of a bedded deposit, the thickness of the salt series, and in the case of a salt dome, the thickness of the salt complex, as well as their extension, should be adequate for the determination of the safety pillars (roof and floor shelves), boundary pillars, within the deposit boundaries, together with the delineation of the protection zone around the site. In the case of the bedded deposits, the type and thickness of the impermeable layers of the overburden and floor can be taken into account when determining the protection zones.

\section{Rock mass strength and convergence}

The salt rock mass is characterized by particular geomechanical properties which may provide the long-term stability of salt chambers. That is one of the most important features for the selection of salt mines as waste disposal sites. At the same time, as a result of salt creep, a continuous rock mass distortions and deformations occur, visible in e.g. the convergence of workings.

The workings selected for the disposal site must be designed in such a way as to maintain geomechanical stability during the required period, and the rock mass deformations should not cause any threat of the loss of sealing or undesired land surface deformations.

\section{The number of aquiferous levels, with the parameters of underground waters; underground water flow rates and directions within the rock mass}

The hydrogeological conditions occurring in the salt deposit and its surroundings play a key role for the underground waste disposal site placement. The salt rock mass is basically tight and impermeable for liquids and gases. However, the salt deposits may contain internal brines (waters), and the rock salt tightness can be disturbed by mining operations. The appearance of waters from outside the deposit, or the so-called external brines in a salt mine should be recognized as the basis for site disqualification.

The occurrence of aquifers within rock formations surrounding the salt deposit is not desired and it presents a direct or potential threat to the disposal site. Recognition of the threat is associated with the identification of aquifers, their characteristics and the way of the contact with the deposit. Underground waters surrounding the deposit do not present any direct threat if there is a natural isolation between the respective aquifers and the deposit, or if the safety pillars and protection zones can stop water inflow. In the case of each salt deposit and its surroundings, it is necessary to carry out detailed hydrogeological research. 
The research goal is to determine either in long-term conditions or in the case of a catastrophic destruction of the deposit's protection barriers:

- By what routes, in what quantities, and at what rates can the deposited substances potentially migrate from the disposal site?

- By what routes and at what rates will they be transported across the deposit and the surrounding rock formations?

- What contamination or pollution of aquifers can be caused and what will be the range of such pollution?

\section{The overburden's permeability}

The isolation of aquifers in the overburden is provided in salt mines by the preservation of safety shelves set within the rock salt bed. The permeability of the overburden is important for the determination of the hydrogeological conditions existing in the deposit's surroundings and for the risk analysis under a disaster scenario in the case of water inflow.

\section{Fracturing of the rock mass creating the pathways for the migration of water solutions with corrosive properties}

Owing to the natural tightness and very small permeability of rock salt, the studies on fracturing and permeability should be referred only to certain zones and salt bed rocks (e.g. the anhydrite layers), which could become the pathways for the migration of salt solutions. The fracturing of the rock mass can also occur in the surrounding rocks of the salt deposit or within the deposit contact zone. The studies of the rock medium in that respect will allow us to recognize the underground water migration paths and potential pathways of pollution propagation in the case of a catastrophic destruction of protection barriers around the deposit.

\section{The reactivity of rocks affected by solutions, including swelling, soaking, and dissolution}

When in contact with water and other solutions, salt deposit rocks (rock salt, potassium salt, and zuber) dissolve, and they can also soak and swell (salty silt rocks and salty clays). Such phenomena influence the mechanical strength of the rocks and can create new paths for substance migration within the salt deposit. In the case of long-term waste deposition, we cannot exclude any undesired reactions among the materials which constitute the artificial barrier, waste, and geological environment, though the salt deposit environment is recognized to be neutral. The evaluation of the possibility of chemical reactions of particular site components should be conducted on the basis of proper geochemical studies. 


\section{The volume of underground water inflow into the workings}

In salt mines, the rock mass is tight and the water inflow into the workings is insignificant. The most suitable site for an underground waste disposal facility is presented by a salt rock mass bereaved of water influx. Underground waters can occur in salt deposits as internal concentrated brines, and, in the case of a disaster, as external waters. The influx of underground waters from outside the deposit makes it impossible to provide for the isolation of waste in the disposal site and it creates a direct threat to the salt mine. The influx of internal waters to the disposal site is not desired. Such solutions can create chemically aggressive environments, accelerating the destruction of artificial barriers and reacting with the deposited substances. That would support the process of the destruction of the site's isolation system. The site area should be fully protected against any inflow of internal brines.

\section{Temperature and pressure within the rock mass}

The temperature and the lithostatic pressure within the salt deposit are directly correlated with depth. An increase in temperature within the depth (geothermal gradient) can be important in the case of deep waste disposal especially in reference to the waste whose physical and chemical durability depends on ambient temperature. With increasing depth, we should expect an increase in the intensity of the deformation occurring in the salt rock mass, e.g. increased convergence of workings as a result of salt creep.

\section{Site location in respect of other workings, taking into account current natural hazards from: water, methane, gas and rock ejection, coal dust explosion, rockbursts}

Natural hazards which appear in salt mines are associated with the possibility of water inflow into the workings and the presence of methane and other gases in the salt bed.

The following are determined in salt mines:

- methane hazard (two categories of hazard),

- gas and rock ejection hazard (three categories of hazard),

- water hazard (three degrees of hazard).

Water hazard is the most serious threat, and it is determined on the basis of the geology of the surrounding rocks: the type of contact with aquifers or underground water basins near the salt bed. In the case of salt domes, always the highest, the third degree of hazard, is assumed. 


\section{CONCLUSIONS}

Underground waste disposal may turn out to be a new direction in the use of abandoned workings within the salt deposits in Poland. Considerable experience has already been collected in that area mainly in Europe. However, such operations are still new and complex in respect of the required research and technologies.

The decision about the suitability of the salt-mine workings for underground disposal of specific types of waste, with application of proper disposal technology, can be made on the basis of the documentation proving long-term site safety.

In Poland, the regulations concerning e.g. the principles of underground waste disposal siting were issued in recent years. Hydrogeological and geological-engineering documentation must be the basis of site selection. Such documentation should present the result of studies describing specific geological conditions determined in the regulations, existing in the selected rock formations. A preliminary geological analysis of the site conditions provided in this paper indicates that, in reference to salt deposits, such conditions must be supplemented with additional details, with the determination of the scope of studies which will be the basis of drafting the required geological documentation.

This study was conducted under the scope of statutory research projects of the AGH University of Science and Technology in 2013, project no 11.11.100.775.

\section{REFERENCES}

Behnsen H., 2008. Underground repositories for chemically toxic waste in German salt and potash mines. [in:] Rempe N.T. (Ed.), Deep Geologic Repositories: Geological Society of America. Reviews in Engineering Geology, 19, 31-40.

Council Decision of 19 December 2002 establishing criteria and procedures for the acceptance of waste at landfills pursuant to Article 16 of and Annex II to Directive 1999/31/EC. 2003/33/EC.

Kunstman A., Lepiarz J., Poborska-Młynarska K. \& Urbańczyk K., 2007. Wstępne koncepcje likwidacji Kopalni Soli Kłodawa: Likwidacja poprzez planowe zatopienie kopalni. Wstępna analiza możliwości wykorzystania wyrobisk kopalni do składowania odpadów. Gospodarka Surowcami Mineralnymi. Przegląd Solny, 23, 1, 77-102.

Poborska-Młynarska K., Piotrowski Z. \& Mazurkiewicz M., 2001. Próba ustalenia geologiczno-górniczych warunków lokalizacji składowiska odpadów niebezpiecznych w wyrobiskach polskich kopalń podziemnych. Przegląd Górniczy, 7-8, 13-20.

Rozporządzenie Ministra Środowiska z dnia 28 grudnia 2011 r. w sprawie podziemnych składowisk odpadów. Dz. U. 2011, nr 298, poz. 1771.

Ustawa z dnia 9 czerwca 2011 r. - Prawo geologiczne i górnicze. Dz. U. 2011, nr 163, poz. 981. 
www.ks-entsorgung.com [access: December 2013].

www.uev.de/frame/frameset.html [access: December 2013].

www.veoliaenvironmentalservices.co.uk/Main/Services/For-business/Hazardous-waste/Underground-storage [access: December 2013].

\section{Streszczenie}

Koncepcja składowania określonych grup odpadów w podziemnych kopalniach soli opiera się na wykorzystaniu środowiska skalnego jako bariery geologicznej powstrzymującej migrację szkodliwych substancji. Unijne i krajowe prawo określa geologiczne warunki lokalizacji i bezpieczeństwa podziemnego składowiska odpadów. Według krajowych przepisów lokalizacji podziemnego składowiska dokonuje się na podstawie wyników badań zawartych w dokumentacji hydrogeologicznej oraz geologiczno-inżynierskiej, określających wskazane warunki geologiczne charakteryzujące wybrane formacje skalne w związku z podziemnym składowaniem odpadów. W artykule przeanalizowano te warunki w odniesieniu do złóż i kopalń soli. Ich wstępna analiza wykazała, że wymagają one uszczegółowienia, a co za tym idzie - określenia zakresu badań będących podstawą oceny środowiska geologicznego w kopalni soli pod kątem wykorzystania jej wyrobisk na składowisko. 